\title{
Effects of progesterone and medroxyprogesterone acetate on egg recovery from the vagina of rabbits
}

\author{
Takeda, Tetsuo, Hiroyuki Suzuki, Shigeru Matsui, Yutaka Terami, \\ and Yoshio TsutsumI
}

Department of Animal Science, Faculty of Agriculture, Hokkaido University, Sapporo 060, Japan

\begin{abstract}
SUMMARY. An experiment was conducted to determine whether the administration of progesterone or medroxyprogesterone acetate (MPA) affects the recovery of the eggs from the vagina and the subsequent fertility and implantations in the rabbit. The does were divided into 6 groups according to dose and time of administration of the gestagen. Vaginal washings for recovery of eggs were carried out twice per day for 7 days following the mating.

Subcutaneous administration of $2.5 \mathrm{mg}$ progesterone on day $-2,-1$ and 0 gave rise to a maximal recovery of vaginal eggs (40.8 $14.8 \%$ in group 2$)$, and intramuscular injection of $25 \mathrm{mg}$ progesterone on day 0 (the day of mating) led to the lowest egg recovery $(6.9 \pm 4.7 \%$ in group $5, \mathrm{p}<0.01)$. The earliest eggs recovered from the vagina were obtained at the first vaginal washings 24 hours after mating in groups 1, 2, 3 and 6. And $80 \%$ in group 1,96\% in group 2, $77 \%$ in group 3, $71 \%$ in group $4,0 \%$ in group 5 and $78 \%$ in group 6 of all eggs, which were collected vaginally for 7 days following the mating, were recovered by 72 hours after mating.

Implantation of eggs in the treated rabbits were examined on day 9 by laparotomy, and $24.3 \pm 15.7 \%$ and $55.6 \pm 16.1 \%$ of eggs were found to be implanted in group 4 and group 5, respectively. No implantations occurred in any other groups. Normal-looking cleaved or fertilized eggs were recovered only in group 3 and group 4; one 2-cell egg and two 4-cell eggs in group 3, one 32-cell egg, two morulae and one blastocyst in group 4. The proportions of unfertilized eggs were $80 \%$ for group $1,88 \%$ for group 2, 46\% for group 3, 50\% for group 4, 20\% for group 5, and 96\% for group 6 .

The results in the present study indicated that administration of progesterone or MPA greatly affected the fertilization and the egg transport in the rabbit.
\end{abstract}

(Japan. J. Anim. Reprod. 24, 184 191, 1978)

\section{Introduction}

In general, about 72 to 96 hours are required for transporting eggs to pass through the oviduct in normal untreated rabbits ${ }^{1 \sim 3)}$, and administration of estrogen ${ }^{4 \sim 12)}$, prostaglandin ${ }^{13 \sim 19)}$ or progesterone were found to cause a disturbance of the egg transport. $\mathrm{CHANG}^{4}{ }^{20}$ ) demonstrated that treatment with progesterone or medroxyprogesterone acetate (MPA) for 3 successive days before ovulation led to a maximal acceleration of the egg transport in rabbits, and as a result he found several eggs in the vagina. PAUERSTEIN et $a l^{21)}$. recovered a few eggs from the vagina of the rabbit treated with progesterone 20 hours after ovulation stimuli at autopsy. Experiments on the effects of dose, time and routes of administration of progesterone on the egg transport showed that a maximal acceleration of the egg transport occurred when $2.5 \mathrm{mg}$ progesterone was given on day $-2,-1$ and $0^{22,23)}$. However, the proportion and the time of eggs expelled into the vagina of rabbit treated with progestational compounds have not been examined because egg transport 
Table 1. Administrations of progesterone or MPA to rabbits

\begin{tabular}{ccccll}
\hline \hline Group & Gestagen & $\begin{array}{l}\text { No. of } \\
\text { does }\end{array}$ & $\begin{array}{c}\text { Dose } \\
(\mathrm{mg} \times \text { times })\end{array}$ & $\begin{array}{l}\text { Route of } \\
\text { adminis- } \\
\text { tration }\end{array}$ & Time of treatment \\
\hline 1 & $\mathrm{P}^{\mathrm{a}}$ & 6 & $2.5 \times 3$ & I. M. ${ }^{\mathrm{b}}$ & Day $-2,-1,0^{\mathrm{c}}$ \\
2 & $\mathrm{P}$ & 6 & $2.5 \times 3$ & S. C. & Day $-2,-1,0$ \\
3 & $\mathrm{P}$ & 5 & $25.0 \times 3$ & S. C. & Day $-2,-1,0$ \\
4 & $\mathrm{P}$ & 5 & $25.0 \times 1$ & I. M. & Day -1 \\
5 & $\mathrm{P}$ & 6 & $25.0 \times 1$ & I. M. & Day 0 \\
6 & MPA $^{\mathrm{e}}$ & 5 & $2.5 \times 3$ & Oral & Day $-2,-1,0$ \\
\hline
\end{tabular}

a : Progesterone.

b : Intramuscular injection.

c : Day of mating designated as day 0 .

$d$ : Subcutaneous injection.

e : Medroxyprogesterone acetate.

surveys have been mainly focused on the oviduct. The present study deals with the egg expulsion into the vagina in progesteroneor MPA-treated rabbits.

\section{Materials and Methods}

Thirty-three sexually mature Japanese White female rabbits were mated twice with fertile males, and $40 \mathrm{IU}$ of HCG was injected intravenously to secure ovulation. The does were divided into six groups according to dose, time and route of gestagen administration (Table 1). The day of mating was designated as day 0. Progesterone was dissolved in sesame oil in concentrations of 2.5 and $25 \mathrm{mg} / \mathrm{ml}$, and $1 \mathrm{ml}$ of the oil was injected into each doe. In group 1 (6 does) and group 2 (6 does), $2.5 \mathrm{mg}$ progesterone were injected on day $-2,-1$ and 0 intramuscularly and subcutaneously, respectively. In group 3 (5 does), subcutaneous injections of $25 \mathrm{mg}$ progesterone were made on day $-2,-1$ and 0 . A single intramuscular injection of $25 \mathrm{mg}$ progesterone was made on day -1 in group 4 (5 does) and on day 0 in group 5 (6 does). Medroxyprogesterone acetate (MPA, Provera, Upjohn Co.) was used in group 6 (5 does); one tablet of $2.5 \mathrm{mg}$ of MPA was given orally to each doe on day $-2,-1$ and 0 .
The schedule of gestagen administration was designed according to the reports by $\mathrm{CHANG}^{4}, 20$ ), DE VARGAS et $a l .{ }^{22)}$ and DE VARGAS and PAUERSTEIN $^{23)}$. Vaginal washing $\mathrm{s}^{18,19,24)}$ were made in each animal twice per day for 7 days after mating to recover eggs from the vagina. The does treated with progesterone or MPA were laparotomized on day 9 and the number of corpora lutea and implantation sites were recorded.

\section{Results}

\section{Number of eggs recovered from the vaginae}

In group 1, three eggs were recovered at the first vaginal washing 24 hours after mating, and twenty-one eggs appeared later up to 72 hours after mating (Table 2, Fig. 1). Thirty eggs were recovered during 7 days, and the recovery rate based on the number of corpora lutea was approximately $33 \%$. A subcutaneous injection, in similar treatments as in group 1 , showed a rapid egg transport in group 2, and twelve eggs were recovered at the first vaginal washing 24 hours after mating. The number of eggs in subsequent washings decreased gradually up to 72 hours after mating, and the recovery rate of the eggs was $41 \%$ 
Table 2. Effects of progesterone and MPA on the vaginal egg recovery and fertility in rabbits

\begin{tabular}{clccc}
\hline Group & $\begin{array}{l}\text { No. of corpora } \\
\text { lutea } \\
(\text { Mean } \pm \text { S. E.) }\end{array}$ & $\begin{array}{l}\text { No. of eggs } \\
\text { recovered } \\
\text { during } 7 \text { days } \\
\text { after mating }\end{array}$ & $\begin{array}{l}\text { Recovery rates } \\
\text { (Mean } \pm \text { S. E. \%) }\end{array}$ & $\begin{array}{l}\text { No. of implantation } \\
\text { sites }^{\mathrm{a}} \\
\text { Rate of implanta- }_{\text {tion, \%) }}\end{array}$ \\
\hline 1 & $87(14.5 \pm 1.3)^{\mathrm{b}}$ & 30 & $32.8 \pm 11.7^{\mathrm{b}}$ & 0 \\
2 & $56(9.3 \pm 0.8)^{\mathrm{c}}$ & 25 & $40.8 \pm 14.8^{\mathrm{b}}$ & 0 \\
3 & $41(8.2 \pm 1.6)^{\mathrm{c}}$ & 13 & $30.9 \pm 11.6^{\mathrm{b}}$ & 0 \\
4 & $46(9.2 \pm 0.7)$ & 14 & $28.8 \pm 10.7^{\mathrm{b}}$ & $12(24.3 \pm 15.7)$ \\
5 & $72(12.0 \pm 0.8)$ & 5 & $6.9 \pm 4.7^{\mathrm{c}}$ & $39(55.6 \pm 16.1)$ \\
6 & $55(11.0 \pm 1.1)$ & 23 & $38.8 \pm 9.0^{\mathrm{b}}$ & 0 \\
\hline
\end{tabular}

a: Number of corpora lutea and implantation sites were recorded on day 9 by laparotomy.

b, c: Significance of difference between $b$ and $c(p<0.01)$.

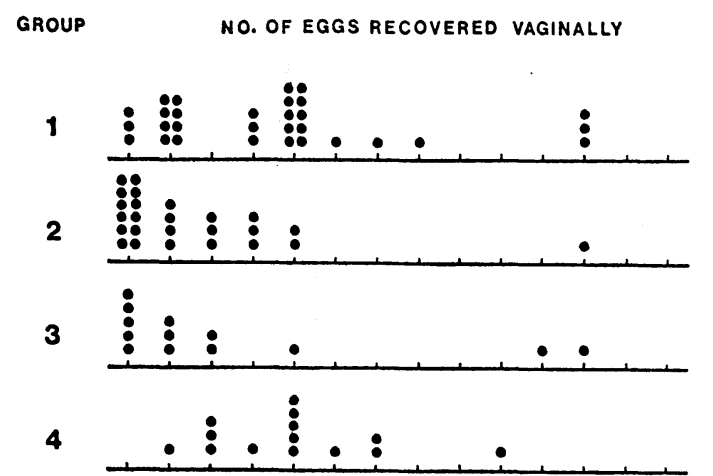

5

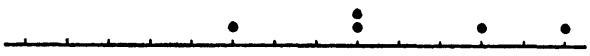

6

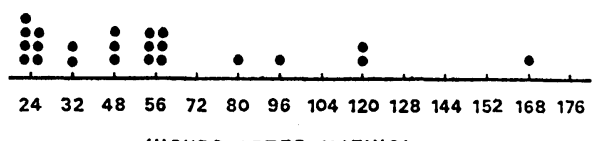
(HOURS AFTER MATING)

Fig. 1. Number of eggs recovered vaginally from rabbits treated with progesterone (groups 1 to 5) or MPA (group 6).

- , Egg recovered.

in group 2. When the dose of progesterone was incresed to ten fold in group 3, a similar pattern of the egg expulsion as seen in group 2 was recognized, although the recovery rate (31\%) decreased.

In group 4, a single intramuscular injection of $25 \mathrm{mg}$ of progesterone was made on day -1 . One egg appeared at the second vaginal washing 32 hours after mating and 13 eggs were recovered by 96 hours continuously with $23 \%$ of recovery rate. This group showed that the appearance of the eggs in the vagina was delayed to some degree in comparion with those in groups 1 to 3 . In group 5, a similar administration as in group 4 was made on day 0 , the results showed a lesser acceleration of the egg transport. No eggs appeared up to 72 hours after mating and only five eggs were recovered from 80 to 176 hours after mating. The recovery rate (7\%) was lowest in this group.

Oral administration of $2.5 \mathrm{mg}$ MPA for 3 successive days in group 6 showed a remarkable acceleration of the egg transport similar to that as seen in group 1 and group 2, and the recovery rate was $39 \%$.

There were similar tendencies in the egg recovery from the vagina in each group except for group 5, and $80 \%$ in group 1, 96\% in group 2, 77\% in group 3, 71\% in group 4, $0 \%$ in group 5 and 78\% in group 6 of all eggs, which were collected vaginally for 7 days following the mating, were recovered by 72 hours after mating.

\section{Developmental stages of eggs recovered}

Normal-looking cleaved or fertilized eggs were recovered only from 2 does in group 3 and from one doe in group 4 . The eggs included one 2-cell egg and two 4-cell eggs in 
Table 3. Stages of development of eggs recovered from the vagina of rabbits treated with progesterone or MPA

\begin{tabular}{|c|c|c|c|c|c|c|}
\hline \multirow{2}{*}{ Morphology of eggs } & \multicolumn{6}{|c|}{ Group } \\
\hline & 1 & 1 & 3 & 4 & 5 & 6 \\
\hline Unfertilized & $24(14)^{\mathrm{a}}$ & $22(4)$ & $6(3)$ & $7(6)$ & 1 & $22(5)$ \\
\hline Undivided & & & 4 & & & \\
\hline Degenerating & 6 & 3 & & 3 & 3 & \\
\hline Empty zona pellucida & & & & & 1 & 1 \\
\hline 2-ecll & & & 1 & & & \\
\hline 4-cell & & & 2 & & & \\
\hline $32-$ cell & & & & 1 & & \\
\hline Morula & & & & 2 & & \\
\hline Blastocyst & & & & 1 & & \\
\hline
\end{tabular}

a: Figures in parenthesis show the number of degenerating eggs.

group 3, and one 32-cell egg, 2 morulae and one blastocyst in group 4 (Table 3). Finally, most of the eggs recovered in the present study were classified as unfertilized eggs, and the proportion of these eggs versus the number of eggs recovered was $80 \%$ in group $1,88 \%$ in group 2, 46\% in group 3, 50\% in group 4, $20 \%$ in group 5 and $96 \%$ in group 6.

\section{Effect of progesterone or MPA on} fertility

The does in group 1, which received intramuscular administration of $2.5 \mathrm{mg}$ progesterne for 3 consecutive days prior to ovulation, showed a maximal number of corpora lutea per rabbit among the groups (Table 2), although it was shown that similar treatments with the exception of subcutaneous injections in group 2 significantly decreased the number of corpora lutea. Furthermore, the largest dose of progesterone in group 3 gave the lowest number of corpora lutea among the groups. The results from the groups 1 to 3 showed a difference between intramuscular injection and subcutaneous injection, however, a single intramuscular injection of $25 \mathrm{mg}$ progesterone on day -1 in group 4 resulted in a similar numer of corpora lutea as in groups 2 and 3. The number of corpora lutea in group
5 increased beyond that in group 4, but the difference between them was not significant. Although the number of corpora lutea in group 1 was significantly large in comparison with those in groups 2,3 and 4, it was difficult to draw a conclusion as to the effect of gestagen on the number of corpora lutea.

Sites of implantation on day 9 were recognized only in groups 4 and 5 (Table 2). Two of 5 does $(40 \%)$ in group 4 , and 5 of 6 does (83\%) in group 5 were pregnant, and conception was seen in $24 \%$ and $56 \%$ of the total number of corpora lutea, respectively.

\section{Discussion}

According to GreEnWALD ${ }^{25)}$, a single injection of $5 \mathrm{mg}$ progesterone given to rabbits immediately after mating accelerated the egg transport to the uterus, but no eggs entered into the uterine lumen within 2 days after mating. BLACK and ASDELL ${ }^{26)}$ reported that $27 \%, 22 \%$ or $0 \%$ of eggs were found in the rabbit uterus 60 hours after mating when 50 , 12 or $0 \mathrm{mg}$ of progesterone were given a few hours after mating, respectively, and they concluded that progesterone failed to show a significant acceleration of the egg transport and was effective only when it could overcome 
the effect of endogenous estrogen. On the contrary, PAUERSTEIN et al..$^{21}$ and CHANG') described that progesterone given prior to ovulation accelerated the egg transport through the oviduct, but did not increase the rate of transport through the oviduct when administered after ovulation. In experiments by $\mathrm{CHANG}^{4}{ }^{5)}, 71 \sim 91 \%$ of eggs recovered fom the uterus on day 2 by administrations of $2 \mathrm{mg}$ MPA before ovulation, and $94 \%$ of the eggs were found in the uterus 40 hours after the transplantation of fertilized eggs in the oviduct of rabbits treated with MPA previously. In a similar experiment by $\mathrm{CHANG}^{20)}, 20 \sim 68 \%$ of eggs were recovered from the uterus on day 1 and $27 \sim 82 \%$ on day 2, and several eggs were found in the vagina on day 2 , when $1 \sim 4$ $\mathrm{mg}$ progesterone were administered for 3 days prior to ovulation. PAUERSTein et al. ${ }^{2)}$ described that when $2.5 \mathrm{mg}$ progesterone were administered in rabbits on the day of HCG injection and on each of the 2 proceeding days, only $37 \%$ of eggs were recovered from the oviduct, whereas $39 \%$ of eggs were found in the uterus, but no attempt of vaginal egg recovery was made 20 hours after HCG treatment. In a previous report by PAUERSTEIN et $a l .{ }^{21)}$, however, a few eggs were recovered by flushing the vagina of does treated with progesterone 20 hours after HCG injection. The results of the present study showed that administration of $2.5 \mathrm{mg}$ or $25 \mathrm{mg}$ progesterone or $2.5 \mathrm{mg}$ MPA for 3 successive days prior to ovulation accelerated the egg transport and caused expulsion of eggs into the vagina from 24 hours after mating. Thus, the egg expulsion into the vagina in the present study occurred 24 or 66 hours earlier than those in estrogen-treated rabbits $^{11,12)}$ or in pseudopregnant does ${ }^{24)}$, respectively.

DE VARGas et $a l .{ }^{22)}$ and DE VARGAS and
PAUERSTEIN ${ }^{23)}$ examined the effect of progesterone on the egg transport in various dosages and time of administration. The maximal acceleration was attained by injection of 2.5 $\mathrm{mg}$ progesterone on day $-2,-1$ and 0 , and the rate of egg recovery from the oviducts was $34 \%$ on day 1 . However, a single dosage on day -1 or on day 0 did not affect the egg transport. They emphasised that treatment of progesterone for acceleration of the egg transport must be started earlier than 12 hours prior to ovulation but not more than 60 hours, and suggested that the mechanisms has an effective life of only about 3 days after the initial dose of progesterone. In the present study, a maximal number of eggs appeared vaginally during 24 to 32 hours after mating, and this period corresponded to 72 hours later from the first injection on day -2 (groups 1, 2, 3 and 6). A similar pattern of the egg expulsion was seen in group 4 treated with $25 \mathrm{mg}$ of progesterone on day -1 , also.

Most of the eggs recovered vaginally in the present study were degenerated and/or unfertilized. This means that progesterone or MPA treatments may affect fertilization of eggs or sperm transport in the female reproductive tract, as reported by BOYARSKY et $a l .{ }^{27)}$, $\mathrm{CHANG}^{20)}$, and Chang and HUNT ${ }^{28}$. Pigs also showed lower fertilization, when progesterone was given prior to ovulation ${ }^{29)}$. When ovulation was induced artificially during the luteal phase of the cycle or during pseudopregnancy, the rate of fertilization of eggs decreased in cattle $^{30)}$, pigs $^{31)}$, rabbits $^{32)}$, and ferrets ${ }^{33)}$. The fertility in pseudopregnant rabbits increased when semen was deposited into the uterus ${ }^{34)}$, and this indicated that inhibition of fertilization during the luteal phase was due to the disturbance of the sperm ascending mechanisms ${ }^{36)}$. NUTTING and MARES ${ }^{36)}$ observed that 
when semen was deposited into the uterus of rabbits treated with $1 \mathrm{mg}$ of progesterone daily for 6 days, nearly all eggs were fertilized, but when semen was deposited into the vagina, sperm in the oviduct and uterus decreased markedly from 8 to 24 hours after deposition, and were absent in the anterior part at $2 / 3$ of the oviduct until 16 hours after insemination. They concluded that progesterone inhibited the fertilization of eggs primarily by disturbance of sperm transport in the female reproductive tract.

Although capacitation of spermatozoa could be achieved in the oviduct of pseudopregnant rabbits, it was inhibited in the uterus of pseudopregnant or progesterone-treated rabbits $^{37)}$. In women, sperm transport through the cervical mucus was inhibited by gestagen, but ovulation did not inhibited ${ }^{38,30)}$. Thus, in animals treated with gestagen, the major part of sperm ejaculated into the vagina may not traverse the cervical mucus to the uterus, and the sites for sperm capacitation may be limited to a small area.

While, various experiments have been conducted regarding the effects of progesterone on the development of rabbit eggs in vivo and in vitro. Although feeding progesterone before or after ovulation had no effect on the development of eggs, subcutaneous injections of progesterone or feeding with MPA before ovulation induced a complete degeneration of eggs on day $6^{4)}$. Small amounts of progesterone given before ovulation resulted in normal fertilization rates and morphologically normal-looking blastocysts, but a drastic reduced implantation was seen ${ }^{40)}$. However, CHANG ${ }^{20)}$ claimed that many of the unfertilized and fertilized eggs recovered from the uterus of the progesterone-treated rabbits were degenerating, and eggs recovered from the ovi- duct, whether fertilized or not, were normal. This observation indicates that the uterine environmental factor may play some role on the embryo development. Regarding this in vitro examinations showed that progesterone inhibited the cleavage of egg $^{41}{ }^{41}$. Most of the eggs recovered vaginally in the present study were degenerated, particularly more than $90 \%$ of the eggs recovered by 72 hours after mating showed severe degeneration.

It has been shown that uterine secretory proteins, particularly uteroglobin, controlled egg development ${ }^{42)}$ and that uteroglobin was embryotoxic if eggs were delivered to the uterus at the wrong time ${ }^{43)}$. Precise examinations of uterine fluid protein pattern of the rabbit treated with progesterone showed that the total uterine fluid protein levels were significantly greater on day 4, particularly the secretion of uteroglobin showed a significant increase by day 3 as compared with that of controls, and that asynchronous uterine fluid proteins in the progesterone-treated rabbit were embryotoxic because embryos residing in progesterone-treated rabbits up to 3 days survived normally when transferred to normal recipients, whereas day 4 embryos from treated animal exhibited a reduced ability to be implanted ${ }^{44)}$. Although some of the vaginal eggs recovered from the rabbit treated with estrogens $^{11,12)}$ and with prostaglandin $\mathrm{F}_{2 \alpha}{ }^{18)}$ developed to young after transfer to recipients, the viability of the vaginal eggs recovered from does treated with progesterone or MPA were not examined because most of the eggs were unfertilized and/or degenerated in the present study.

Acknowledgment. The authors are grateful to the Teikoku-zoki Co., Ltd., Japan, for supplying progesterone. This work was supported in part by a Research Project Grant (Project No. 148065) 
from the Ministry of Education, Japan.

\section{References}

1) Howe, G.R.: J. Reprod. Fertil. 21, 339, 1970.

2) Pauerstein, C. J., V. Anderson, M. L. Chatkoff \& B. J. Hodgson: Amer. J. Obstet. Gynecol. 120, 299, 1974.

3) Tsutsumi, Y. \& E. S. E. Hafez: J. Morphol. 144, 323, 1974.

4) Chang, M. C.: Endocrinology 79, 939, 1966.

5) Chang, M. C.: Nature 212, 1048, 1966.

6) Chang, M. C. \& R. Yanagimachi: Fertil. Steril. 16, 281, 1965.

7) Chang, M. C. \& M. J. K. HARPER: Endocrinology 78, 860, 1966.

8) Greenwald, G. S.: J. exp. Zool. 135, 461, 1957.

9) Greenwald, G. S.: Fertil. Steril. 10, 155, 1959.

10) Greenwald, G. S.: J. Endocrinol. 26, 133, 1963.

11) Tsutsumi, Y., T. Takeda, K. Yamamoto \& Y. TANABE: J. Reprod. Fertil. 48, 393, 1976.

12) Takeda, T., K. Yamamoto, Y. Tanabe. \& Y. Tsutsumi: Memoirs Facul. Agr. Hokkaido Univ. 10, 231, 1977.

13) Ellinger, J. V. \& K. T. Kirton: Biol. Reprod. 7, 106, 1972, (abstr).

14) Ellinger, J. V. \& K. T. Kirton: Biol. Reprod. 11, 93, 1974.

15) Chang, M. C. \& D. M. Hunt: Nature 236, $120,1972$.

16) Chang, M. C., D. M. Hunt \& C. Polge: $A d v$. Biosci. 9, 805, 1973.

17) AREF, I., E. S. E. HAFez \& G. A. R. KamaR: Fertil. Steril. 24, 671, 1973.

18) Takeda, T., Y. Tsutsumi, Y. Tanabe \& K. Yамамото: Fertil. Steril. 28, 759, 1977.

19) Takeda, T., Y. Tsutsumi, S. Hara \& M. IDA: Fertil. Steril. 30, 79, 1978.

20) Chang, M. C.: Endocrinology 81, 1251, 1967.

21) Pauerstein, C. J., B. D. Fremming \& J. E. MARTIN: Gynec. Invest. 1, 257, 1970.

22) De Vargas, M. I. G., B. J. Hodgson \& C. J. Pauerstein: Obstet. Gynec. 46, 299, 1975.

23) De Vargas, M. I. G. \& C. J. Pauerstein: In Ovum Transport and Fertility Regulation (Harper, M. J. K., C. J. Pauerstein, C. E. adams, E. M. Coutinho, H. B. Croxatto \& D. N. PAton eds.) p. 515, Copenhagen, Scriptor. 1976.

24) Tsutsumi, Y. \& T. TAKeda: Jap. J. Zootech. Sci. 47, 509, 1976.

25) Greenwald, G. S.: Fertil. Steril. 12, 80, 1961.

26) BlaCK, D. L. \& S. A. Asdell: Amer. $J$. Physiol. 197, 1275, 1959.

27) Boyarsky, L. H., H. Baylies, L. E. Casida \& R. K. MEYER: Endocrinology 41, 312, 1947.

28) Chang, M. C. \& D. M. Hunt: Fertil. Steril. 21, 683, 1970.

29) Day, B. N. \& C. Polge: J. Reprod. Fertil. 17, 227, 1968.

30) Casida, L. E., R. K. Meyer, W. H. MaShan \& W. Wisnicky: Amer. J. Vet. Res. 4, 76, 1943.

31) Tanabe, T. Y., A. C. Warnick, L. E. Casida \& R. H. Grummer: J. Anim. Sci. 8, 550. 1949.

32) Murphree, R. L., E. J. WARWiCK, L. E. CASIDA \& W. H. McShaN: Endocrinology 41, 308, 1947.

33) Chang, M. C.: J. Reprod. Fertil. 13, 173, 1967.

34) Murphree, R. L., W. G. Black, G. Otto \& L. E. CASIDA: Endocrinology 49, 474, 1951.

35) Dobrowolski, W. \& E. S. E. HaFez: Amer. J. Vet. Res. 31, 2243, 1970.

36) Nutting, E. F. \& S. E. Mares: Biol. Reprod. 2, 230, 1970 .

37) Chang, M. C.: Endocrinology 63, 619, 1958.

38) Martinez-Manautou, J., V. Cortez, J. Giner, R. Aznar, J. Casasola \& H. W. Rudel: Fertil. Steril. 17, 49, 1966.

39) Rolland, M.: Int. J. Fertil. 13, 390, 1968.

40) Allen, M. C. \& R. H. Foote: Fertil. Steril. 24, 220, 1973.

41) Daniel, J. C. \& J. D. Levy: J. Reprod. Fertil. 7, 323, 1964.

42) BeIER, H. M.: J. Reprod. Fertil. 37, 221, 1974.

43) Maurer, R. R. \& H. M. Beier: J. Reprod. Fertil. 48, 33, 1976.

44) McCarthy, S. M., R. H. Foote \& R. R. MaURer: Fertil. Steril. 28, 101, 1977. 


\title{
Progesterone 及び Medroxyprogesterone acetate 投与が家鬼胵からの採卵に及ぼす影響
}

\author{
武田哲男 - 鈴木裕之・松井 滋 - 寺見 裕 - 堤 義雄 \\ (北海道大学農学部 畜産学科)
}

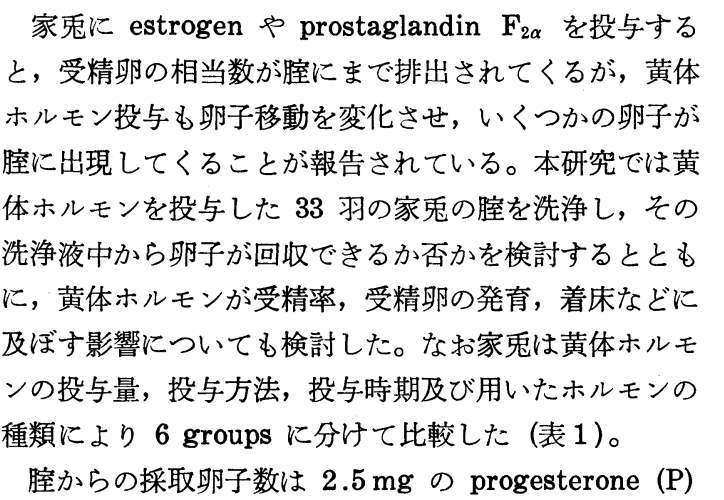
を day $-2,-1 ， 0$ (交配日）の 3 日間皮下注射した 群 (group 2) が最も多く, 黄体数に対する割合（採卵 率）は $41 \%$ であった。最低を示したのは $25 \mathrm{mg}$ の を day 0 に 1 回筋肉内注射した group 5 で, その採 卵率は 7\% であった（表 2, 困 1)。胵からの卵子回収 の傾向をみると, 交配前に 3 回連続投与した群 (groups $1 ， 2 ， 3 ， 6) て ゙ は$, 交配後24時間目の初回胵洗浄ですでに 卵子が採取され始めており, 交配後 72 時間目までの間
に集中して回収された。交配後 72 時間目までに採取さ れた卵子の総採卵数に対する割合は, group 1 で $80 \%$, group 2 で 96\%, group 3 で 77\%, group 4 で 71 $\%$, group 5 で 0\%, group 6 で 78\% であり, P を day 0 に 1 回筋注したのみの group 5 以外は交配後72 時間目までに採取卵子の $70 \%$ 以上が回収された。着床 の有無を day 9 に開腹して調べた結果, $\mathrm{P}$ をday-1 に 1 回筋注した group 4 で黄体数に対し約 $24 \%$, group 5 では約 56\% の卵子の着床部位が数えられたが，他の 群では 1 例の着床も認められなかった。

影微鏡下で正常と思われる分割卵あるいは受精卵が採 取されたのは, group 3 と4のみで, group 3 から 2細胞期卵子 1 個, 4-細胞期卵子 2 個, group 4 から 32細胞期卵子 1 個, 桑実胚 2 個及び胚盤胞 1 個の合計 7 個 が採取されたにすぎず，その他の群では未受精卵が非常 に多く, その割合は group 1 で 80\%, group 2 で 88 \%, group 3 で 46\%, group 4 で 50\%, group 5 で 20\%, group 6 で 96\% であった。 